\title{
Brazilian-Portuguese translation, cross-cultural adaptation and validation of the Myasthenia Gravis Composite scale. A multicentric study
}

Tradução,adaptação cultural e validação da escala composta de Miastenia Grave para a lingua portuguesa do Brasil. Estudo multicêntrico

Ezequiel Fernandes Oliveira1, Valéria Cavalcante Lima², Eduardo Araujo Perez³, Melissa Nunes Polaro4, Berenice Cataldo Oliveira Valério ${ }^{4}$, João R Pereiro ${ }^{5}$, Sergio Roberto Nacif ${ }^{5}$, Claudia Santos Oliveira ${ }^{7}$, Acary Souza Bulle Oliveira², Luis Vicente Franco Oliveira ${ }^{1}$

\begin{abstract}
Objective: To perform the translation, cultural adaptation and validation of the Myasthenia Gravis Composite (MGC) scale in Brazil. Methods: The study was conducted at three neuromuscular disease research centers in accordance with the international ethical standards, following a multi-modal approach and was conducted in three steps consisting of translation, cultural adaptation, and validation according to international guidelines. The final version of the MGC was applied in a sample of $27 \mathrm{MG}$ patients and the total score was compared to a Portuguese version of the MG-QOL-15. Results: The internal consistency verified by Cohen's Kappa test was excellent (0.766). The correlation between the MGC and MG-QOL-15 was strong ( $R=0.777 ; p=0.000)$. No significant differences were found between the responses of patients in the first and second applications of the MGC. Conclusion: The MGC scale, validated into Brazilian Portuguese, has proven to be a reliable instrument that is easy to use, and is highly reproducible.
\end{abstract}

Keywords: myasthenia gravis; translating; surveys and questionaires.

RESUMO

Objetivo: Realizar a tradução e a adaptação transcultural da escala composta de Miastenia Grave (ECMG) Myasthenia Gravis Composite (MGC) no Brasil. Métodos: 0 estudo foi realizado em três centros de investigação em doenças neuromusculares, de acordo com as normas éticas internacionais, consistindo em tradução, adaptação cultural e validação de acordo com as diretrizes internacionais. A versão final do MGC ECMG foi aplicada em vinte e sete pacientes com MG e a pontuação total foi comparada ao questionário MG-QOL 15. Resultados: A consistência interna verificada pelo teste Kappa de Cohen foi excelente (0,766) e a correlação entre o a ECMG MGC e MG-QOL 15 foi positiva (R=0,777; $p=0,000)$. Não foram encontradas diferenças entre as respostas dos pacientes na primeira e segunda aplicação da MGC. Conclusão: A ECMG escala MGC validada para o Português do Brasil provou ser um instrumento confiável, de fácil aplicação e altamente reprodutivel.

Palavras-chave: miastenia gravis; tradução; inquéritos e questionários.

Myasthenia gravis (MG), a chronic autoimmune disease, is characterized by progressive weakness and fatigue of skeletal muscle caused, in $85 \%$ to $90 \%$ of patients, by antibodies against the acetylcholine receptor (AChR) of the post-synaptic membrane of the neuromuscular junction ${ }^{1}$. There is also a smaller number of patients showing autoantibodies against

\footnotetext{
'Universidade Nove de Julho, Programa de Pós Graduação Mestrado e Doutorado em Ciências da Reabilitação, São Paulo SP, Brasil; ${ }^{2}$ Universidade Federal de São Paulo, Departamento de Neurologia e Neurocirurgia, Divisão de Doença Neuromuscular, São Paulo SP, Brasil; ${ }^{3}$ Faculdade de Ciências Médicas da Santa Casa de São Paulo, Programa de Mestrado e Doutorado em Pesquisa em Cirurgia, São Paulo SP, Brasil; ${ }^{4}$ Faculdade de Ciências Médicas da Santa Casa de São Paulo, Departamento de Clínica Médica, Disciplina de Neurologia, São Paulo SP, Brasil; ${ }^{5}$ Hospital do Servidor Público Estadual, Programa de Pós Graduação em Ciências da Saúde, São Paulo SP, Brasil.

Correspondence: Luis Vicente Franco Oliveira; Laboratório de Sono da UNINOVE; Rua Vergueiro 235/249; 01504-001 São Paulo SP, Brasil; E-mail: oliveira.lvf@pq.cnpq.br

Conflict of interest: There is no conflict of interest to declare.

Support: LVFO received Research Productivity modality IB grants from Conselho Nacional de Desenvolvimento Cientifico e Tecnologico (CNPq; process no. 313053/2014-6) and, EFO receives grants from Fundaçao de Amparo a Pesquisa do Estado de Sao Paulo (FAPESP; protocol no. $2015 / 11738-6$. Received 16 March 2016; Received in final form 01 June 2016; Accepted 20 June 2016.
} 
the muscle-specific kinase (MuSK) or the low-density lipoprotein-related protein 4 (LRP4) and even against agrin².

The prevalence of MG varies from 1.7 to 21.3 cases per million people per year in the general population, mainly affecting individuals aged 20-40 years, and more women than men (ratio 3:2). The mortality rate varies from 0.06 to 0.89 per million people each year ${ }^{3,4}$.

Disease severity depends on the compromised muscle groups, varying from mild, with purely ocular symptoms, to the most serious cases with generalized muscle weakness and respiratory failure ${ }^{1}$. The Myasthenia Gravis Committee Foundation of America (MGFA) categorizes MG into five levels of severity according to the appearance of symptoms and the anatomical distribution of affected muscle groups ${ }^{5}$.

Health Related Quality of Life (HRQoL) is an important component in the evaluation of MG patients, as the disease severity can vary widely. The assessment instruments of HRQoL and clinical progression can be generic or specific to a particular group of diseases, such as $\mathrm{MG}^{6}$. Clinical trials to test new therapeutic interventions require some scale of clinical evaluation to assess the level of disease severity and the response to therapy ${ }^{7,8}$.

Information about clinical evaluation and HRQoL, obtained through specific instruments, enable a better understanding of the patient's needs, and allow provision of adequate clinical support ${ }^{6}$. The more specific the instrument, the more relevant it becomes for evaluation and monitoring of disease progress.

The HRQoL and clinical status measures, obtained through patient-oriented instruments, are considered essential in the evaluation of neurological diseases, especially in those diseases that may affect a patient's general status, such as MG. Patient-derived tools have added a new dimension to clinical outcome evaluation. These are important, both for assessing individual patients in the neurology clinic, and for international comparisons, multicenter trials and other types of collaborations ${ }^{9}$. Previous studies have described a significant correlation between HRQoL and severity of $\mathrm{MG}^{10,11,12}$.

We found only three specific tools for evaluating HRQoL in MG patients in the international scientific literature (Myasthenia Gravis Questionnaire ${ }^{13}$, Myasthenia Gravis-specific Activities of Daily Living Profile ${ }^{14,15}$, Questionnaire of Life Quality Specific for Myasthenia Gravis - 15 items (MG-QOL-15) ${ }^{16}$ ) and two instruments to assess the clinical evaluation of patients with $\mathrm{MG}$ (Quantitative Myasthenia Gravis Score ${ }^{17}$ and Myasthenia Gravis Composite scale (MGC) $)^{18}$ ). From these instruments, only the MG-QOL-15 has been translated into Brazilian Portuguese ${ }^{19}$. Therefore, it was important to study the translation, cultural adaptation and validation of the MGC in Brazilian patients.

\section{METHODS}

The study was conducted at three neuromuscular disease research centers in accordance with the ethical standards established in the 1961 Declaration of Helsinki (as revised in Hong Kong in 1989 and Edinburgh, Scotland in 2000) and complied with the Regulatory Guidelines and Norms for Research Involving Human Subjects of the National Health Board of the Brazilian Health Ministry issued in December 2012. This study is part of a research protocol that was approved by the Human Research Ethics Committee of Nove de Julho University (Brazil) under process no. 360.488 and is registered with the World Health Organization (WHO) under Universal Trial Number (UTN) U1111-1147-7853 and the Brazilian Registry of Clinical Trials (REBEC) RBR -7ckpdd. A written informed consent was obtained, and subjects were allowed to withdraw from the study at any time without consequence.

The study included patients with a clinical diagnosis of MG according to the MGFA, aged 18-75 years, both genders, who were clinically stable and who agreed to participate by signing the informed consent form. We excluded patients with other neuromuscular disorders, episodes of acute clinical decompensation in the two months prior to consideration for inclusion, and those with a history of stroke, mental instability, or drug or alcohol abuse.

\section{The Instrument}

The MGC scale is a valid and reliable instrument used to evaluate the clinical status of patients with MG both in clinical practice, and in scientific research. The scale was validated through tests conducted in 2008 and 2009 in 11 research centers in the United States of America and Europe ${ }^{20}$. The MGC is an ordinal scale, consisting of 10 items, each representing a function commonly affected by MG. The response categories of MGC items are weighted. For example, 'ptosis' scores 3 points, while 'severe weakness of hip flexion' is equivalent to 5 points, and severe respiratory weakness (i.e. ventilator-dependent patients) equates to 9 points. The maximum MGC score is 50 , and directly relates to patient condition i.e., a high score reflects severe disease. A reduction of 3 points in the score may indicate a significant and reliable clinical improvement in patients with MG.

\section{Translation, cross-cultural adaptation, and validation}

The study design followed a multi-modal approach and was conducted in three stages consisting of translation, cultural adaptation, and validation of the MGC according to international guidelines proposed and developed in other linguistic and socio-cultural contexts ${ }^{21,22,23,24,25}$. Figure 1 displays the flowchart of the study. 


\section{Translation}

According to the established protocol previously published $^{26}$, two qualified Brazilian translators, one a professional scientific English translator who is unfamiliar with the area of expertise, the other a bilingual neurologist, performed independent Brazilian Portuguese translations. Then, a committee of four neurologists and two physiotherapists, all bilingual, compared these two initial translations, creating a new, first version of the scale in Brazilian Portuguese. All members of this committee were bilingual university professors and researchers with clinical experience in neuromuscular diseases and had advanced knowledge of the English language.

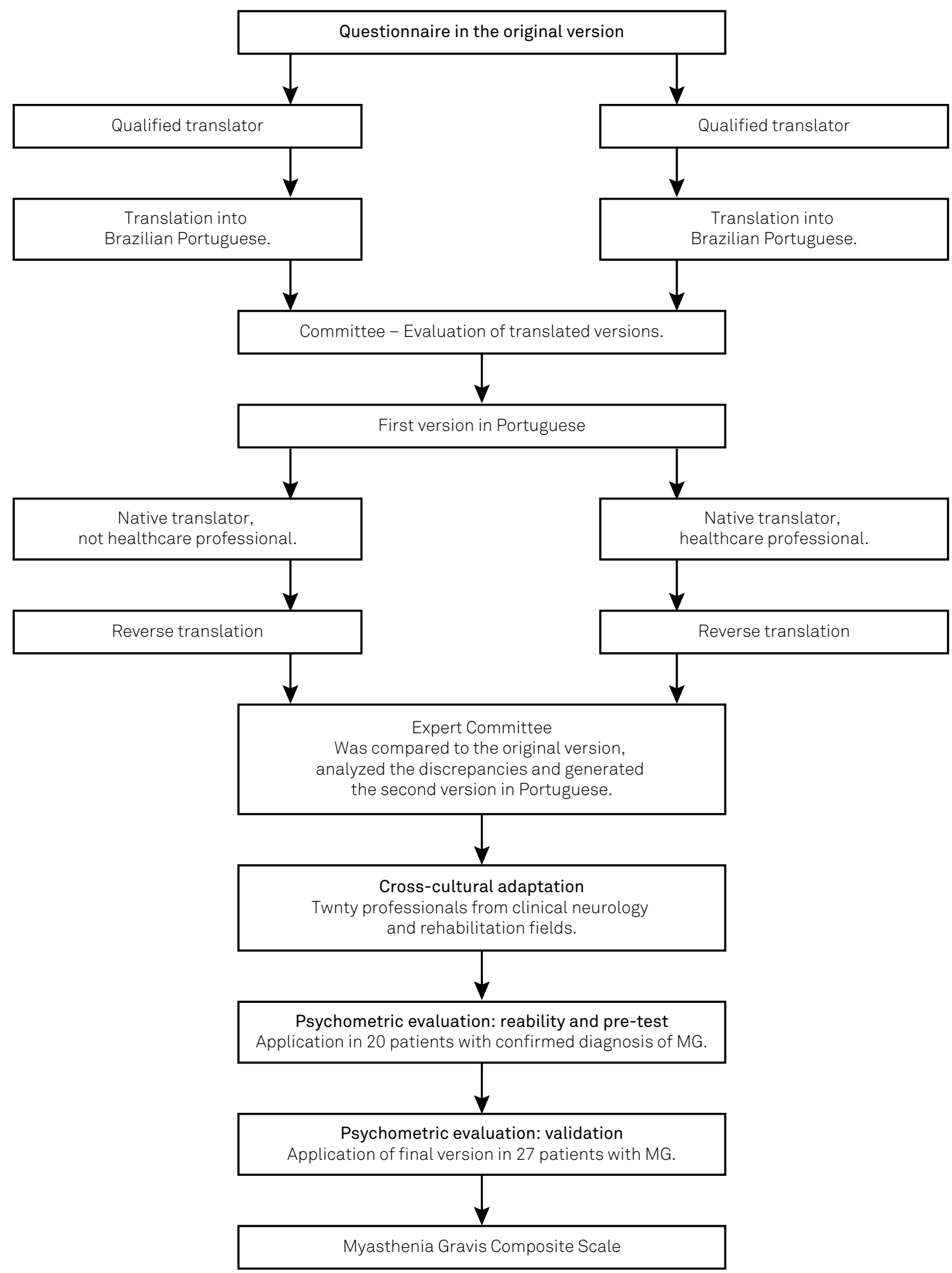

Figure 1. Flow chart of the methodological approach. 


\section{Reverse-translation}

Two nativeEnglish speakers, a layperson and a professional translator, subsequently performed two reverse-translations of the preliminary Brazilian Portuguese version of the scale. These translators were not informed about the study objectives and had no access to the original version. This reversetranslation aimed to prove that the new version was equivalent to the original.

Another expert committee, comprising one methodologist, six health professionals, two native-speaking professionals and the translators, compared the two reverse-translation versions with the original English version of the MGC, made necessary adjustments, and generated the final version in Portuguese. The second Portuguese version of the scale was established after consensus was reached among committee members on each item.

\section{Cross-cultural adaptation}

The second version of the scale, translated into Portuguese, underwent a semantic analysis, and was analyzed by twenty health professionals, specializing in clinical neurology and rehabilitation medicine (10 physicians and 10 physiotherapists), to determine whether the terms used were easy to understand. This step was performed to ensure that the translated items were equivalent to the original, and included an assessment of the degree of understanding of the issues proposed.

Health professionals involved in this research phase made comments about the understanding of the scale. Any ambiguous terms were highlighted and discussed by the members of the study committee, and were replaced by other terms with semantic equivalence, appropriate to Brazilian culture, thereby generating a third version in Portuguese, without compromising the original version.

\section{Psychometric evaluation}

\section{Reliability}

To check inter-rater reliability, the third Portuguese version was administered by 10 health professionals to 20 patients with a confirmed diagnosis of MG (15 women), on two different occasions, at the same time of the day, with an interval of 48 hours, to assess test-retest reliability. These results were used to determine the level of semantic understanding to consolidate the final version of the MGC scale. The final version of the MGC scale translated into Brazilian Portuguese is presented in Figure 2.

\section{Pre-test}

The content validity was assessed qualitatively in a pilot study, in which the patients provided critical feedback on the design, content, and structure of the questionnaire, and in consultation with specialized clinicians in the field. The validity of the questions on the clinical characteristics and disease severity of MG were evaluated retrospectively by the two main investigators. They were blinded to the questionnaire results when registering the symptoms in the medical records of the 20 patients who participated in the pre-test stage.

The self-reported clinical characteristics of the disease at onset were compared with the symptoms reported in the patient's medical record, and the clinical symptoms reported in the medical records were considered to be the closest to a gold standard evaluation of the patients' symptoms.

\section{Validation}

Forty patients (29 women) with a confirmed diagnosis of MG, and classified according to MGFA, were invited to participate in this step of the study. Twenty-seven patients (21 women) accepted, comprising 11 patients from Setor de Investigação de Doenças Neuromusculares da Universidade Federal de São Paulo (UNIFESP), 11 patients from Departamento de Neurologia da Faculdade de Ciências Médicas da Santa Casa de São Paulo (FCMSC), and five patients from Departamento de Neurologia do Hospital do Servidor Público Estadual (HSPE).

Demographic and clinical data were collected, along with details of current MG-related symptoms and therapeutic strategies. We excluded nine patients due to cognitive impairment, illiteracy and/or other chronic diseases and four patients because of a diagnosis of congenital myasthenic syndrome. The final version of the MGC was administered to in a final sample of $27 \mathrm{MG}$ patients and the total score was compared to a Portuguese version of the MG-QOL-15, validated in Brazil, and commonly used to assess quality of life in $\mathrm{MG}^{19}$.

The MG-QOL-15 is an effective, quick, and easy-to-use instrument, consisting of 15 items, graded on a scale of 0-4, evaluating three dimensions of the HRQoL. The highest possible score is 60 points, indicating a poor quality of life as perceived by the patient. These 15 items efficiently evaluate physical, social, and psychological aspects of life, which are essential components for the interpretation of the HRQoL. The instrument does not have a specific cut-off value ${ }^{16,19}$.

\section{Statistical analysis}

Initially, the Shapiro-Wilk test was used to verify the normal distribution of the sample data. Parametric data were expressed as mean and standard deviation, including anthropometric values, age, and the circumferences of the neck and abdomen. Non-parametric data were expressed by standard error.

In the pre-test, we used Cohen's Kappa coefficient for ordinal measures. The Kappa statistic is frequently used to test inter-rater reliability. Rater reliability is important as it reflects the accuracy of the data collected. Measurement of the extent to which data collectors (raters) assign the same score to the same variable is called inter-rater reliability. 


\begin{tabular}{|c|c|c|c|c|}
\hline $\begin{array}{l}\text { Ptose (olhar para cima } \\
\text { facilmente) }\end{array}$ & $>45$ segundos & $11-45$ segundos & $1-10$ segundos & Imediata \\
\hline (exame médico) & 0 & 1 & 2 & 3 \\
\hline $\begin{array}{l}\text { Visão dupla (olhar fixo } \\
\text { lateral) (esquerda ou } \\
\text { direita). }\end{array}$ & $>45$ segundos & $11-45$ segundos & $1-10$ segundos & Imediata \\
\hline (exame médico) & 0 & 1 & 3 & 4 \\
\hline Fechamento dos olhos & Normal & $\begin{array}{l}\text { Fraqueza leve (abertura } \\
\text { com esforço externo) }\end{array}$ & Fraqueza moderada & Fraqueza grave \\
\hline \multirow{2}{*}{ (exame médico) } & 0 & 0 & $\begin{array}{l}\text { (podem ser abertos } \\
\text { facilmente) }\end{array}$ & $\begin{array}{l}\text { (incapaz de manter os } \\
\text { olhos fechados) }\end{array}$ \\
\hline & & & 1 & 2 \\
\hline Fala & Normal & $\begin{array}{l}\text { Gagueira intermitente ou } \\
\text { fala nasal }\end{array}$ & $\begin{array}{l}\text { Gagueira constante ou } \\
\text { fala nasal que pode ser } \\
\text { compreendida }\end{array}$ & $\begin{array}{l}\text { Dificuldade no } \\
\text { entendimento da fala }\end{array}$ \\
\hline (História do paciente) & 0 & 2 & 4 & 6 \\
\hline Mastigação & Normal & $\begin{array}{c}\text { Fadiga com alimentos } \\
\text { sólidos }\end{array}$ & $\begin{array}{c}\text { Fadiga com alimentos } \\
\text { moles }\end{array}$ & Tubo gástrico \\
\hline (História do paciente) & 0 & 2 & 4 & 6 \\
\hline Deglutição & Normal & $\begin{array}{l}\text { Raros episódios de } \\
\text { engasgo ou dificuldade } \\
\text { para engolir = } 2\end{array}$ & $\begin{array}{c}\text { Dificuldade frequente } \\
\text { na deglutição com } \\
\text { necessidade de alteração } \\
\text { na dieta }\end{array}$ & Tubo gástrico \\
\hline (História do paciente) & 0 & & 5 & 6 \\
\hline Respiração & Normal & Dispneia de esforço & Dispneia em repouso & Ventilador dependente \\
\hline (consequência da MG) & 0 & 2 & 4 & 9 \\
\hline $\begin{array}{l}\text { Flexão ou extensão de } \\
\text { pescoço. }\end{array}$ & Normal & Fraqueza leve & Fraqueza moderada & Fraqueza grave \\
\hline (exame médico) & 0 & 1 & $(\sim 50 \%$ fraca $\pm 15 \%)=3$ & 4 \\
\hline Abdução de ombros & Normal & Fraqueza leve & Fraqueza moderada & Fraqueza grave \\
\hline (exame médico) & 0 & 2 & $(\sim 50 \%$ fraca $\pm 15 \%)=4$ & 5 \\
\hline Flexão do quadril & Normal & Fraqueza leve & Fraqueza moderada & Fraqueza grave \\
\hline (exame médico) & 0 & 2 & $(\sim 50 \%$ fraca $\pm 15 \%)=4$ & 5 \\
\hline
\end{tabular}

Nota: Observe que "fraqueza moderada" para os itens pescoço e membros deve ser interpretada como fraqueza equivalente a $50 \% \pm 15 \%$ do esperado para uma força normal. Qualquer fraqueza mais leve do que isto seria classificada como leve e qualquer fraqueza mais grave seria classificada como grave. Total de pontos:

Figure 2. Portuguese-Brazil version of Myasthenia Gravis Composite Scale.

Pearson's rank correlation coefficient was used for correlation of the subjective assessment of MGC and MG-QOL 15. A p value $<0.05$ was considered significant. Statistical analyses were performed with the StatView 5.0 (SAS Institute, Cary, N.C., USA), and SPSS software (version 23.0, SPSS Inc. Chicago, IL, USA).

\section{RESULTS}

There were 27 patients (21 women) with a confirmed diagnosis of MG acquired autoimmune form, and a mean age of $46.55 \pm 11.71$ years, range 32-74 years, enrolled in this study. The average duration of illness in these patients was $11.33 \pm 8.49$ years. According to the classification of MGFA, two patients were class I, 17 were class II, eight were class III, and none were in classes IV and V. Ninety-eight percent of patients were taking cholinesterase inhibitors and $28 \%$ were taking an immunosuppressant. Clinical and demographic features of the MG patients are presented in the Table.

\section{Reliability and validity}

The average time required for completing the MGC by patients was 32 minutes. The expression "ptosis, ascending naturally", in the original version, was replaced by "ptosis, looking up easily". Items used in the evaluation of muscle strength of neck flexion/extension, hip flexion, and shoulder abduction generated the greatest difficulty. Specifically, the grading of muscle weakness as moderate weakness posed problems. The original version emphasizes that moderate weakness should 
Table. Clinical and demographic features of the patients with myasthenia gravis.

\begin{tabular}{lcc}
\hline Variables & Patients $(\mathrm{n}=27)$ & $(\%)$ \\
\hline Female/male & $21 /$ jun & - \\
Age (years) & $46.55 \pm 11.71$ & - \\
\hline Disease classification & & \\
Acquired autoimmune & 27 & - \\
MGFA & & \\
I & 2 & 7.4 \\
IIA & 15 & 55.5 \\
IIB & 2 & 7.4 \\
IIIA & 4 & 14.8 \\
IIIB & 4 & 14.8 \\
MGC score & $12.8 \pm 7$ & - \\
MG QOL - 15 score & $21.7 \pm 12.2$ & - \\
\hline
\end{tabular}

MGFA: Myasthenia Gravis Foundation of America Clinical classification; MGC: Mysthenia Gravis Composite scale; MG-QOL: Questionnaire of Life Quality Specific for Myasthenia Gravis - 15 items.

be equal to approximately $50 \% \pm 15 \%$ of the expected normal force. Accordingly, we added a note explaining how to grade moderate muscle weakness to the final version of the scale.

The internal consistency verified by Cohen's Kappa test was excellent (0.766). Patients scored an average of $12.93 \pm 6.92$ in the MGC scale and an average of $21.38 \pm 12.07$ in the MG-QOL-15 scale. The correlation between the MGC and MG-QOL-15 was strong $(\mathrm{R}=0.777 ; \mathrm{p}=0.000)$. No significant differences were found between the responses of patients in the first and second applications of the MGC.

\section{DISCUSSION}

In recent years, disease-specific, patient-derived questionnaires have becomeimportantmeasures to describe disease severity when compared with generic, patient-derived instruments.

According to our knowledge, this is the first study of the translation and validation of the MGC scale to a language other than English. Translation of the MGC to Brazilian Portuguese was successful, and reverse-translation to English corresponded very well with the original version. The MGC scale was properly translated and culturally adapted following a defined sequence of actions in accordance with the standards for cultural adaptation ${ }^{21,22,23,24,25}$.

In 2012, a Task Force of the Medical Scientific Advisory Board of the MGFA recommended using the MGC as the quantitative measure for determining improvement or deterioration in patients with generalized $\mathrm{MG}^{27}$.

The MGC can be used in daily practice and in clinical trials. This instrument differs from most scales in that it is a hybrid of patient-reported and physician-reported test items. It is not surprising that certain patient-reported test items perform better than their physician-reported examination counterparts, and thus justify inclusion in the MGC.

The validity and reliability of the MGC for measuring disease severity in MG was previously demonstrated using conventional psychometric tests ${ }^{28,29}$.

The evaluation of the HRQoL of a patient can influence therapeutic decisions and provide a better understanding of their needs, allowing the adoption of an appropriate therapeutic strategy ${ }^{16,30}$. A disease-specific instrument may be the most relevant clinical and functional assessment of the disease state, avoiding ineffective approaches ${ }^{28}$.

In the validation phase, the Brazilian version of the MGC was very well understood and accepted by patients and by health professionals. Neither patients nor professionals had difficulties completing the questionnaire. In the validation phase of our study, the MGC was compared with the MG-QOL-15, considered the gold standard HRQoL assessment instrument in MG, with a positive correlation. This result corroborates other studies that validated the use of the $\mathrm{MGC}$ as an evaluation tool in patients with $\mathrm{MG}^{16,18}$.

Factors related to the disease can influence HRQoL in MG, such as the predominant symptoms, the frequency of myasthenic crisis and the therapeutic strategy adopted. The frequency and severity of MG symptoms also influence the perception of HRQoL. Therefore, it is expected that a poor clinical situation will lead to a poor HRQoL result.

In conclusion, the original version of the MGC scale, having been translated, culturally adapted, and validated into Brazilian Portuguese has proven to be a reliable instrument that is easy to use, highly reproducible, and can be used in both clinical practice and clinical trials in the evaluation of patients with MG.

\section{References}

1. Drachman DB. Myasthenia gravis. N Engl J Med. 1994;330(25):1797-810.

2. Patrick J, Lindstrom J. Autoimmune response to acetylcholine receptor. Science. 1973;180(4088):871-2. doi:10.1056/NEJM199406233302507

3. Carr AS, Cardwell CR, McCarron PO, McConville J. A systematic review of population based epidemiological studies in Myasthenia Gravis. BMC Neurology. 2010;10(1):46. doi:10.1186/1471-2377-10-46
4. Mao ZF, Mo XA, Qin C, Lai YR, Hartman TCO. Course and prognosis of myasthenia gravis: a systematic review. Eur J Neurol. 2010;17(7):913-21. doi:10.1111/j.1468-1331.2010.03017.x

5. Jaretzki A 3rd, Barohn RJ, Ernstoff RM, Kaminski HJ, Keesey JC, Penn ASet al. Myasthenia gravis: recommendations for clinical research standards. Ann Thorac Surg. 2000;70(1):327-34. doi:10.1016/S0003-4975(00)01595-2 
6. Cella DF, Tulsky DS. Measuring quality of life today: methodological aspects. Oncology (Willinston Park). 1990;4(5):29-38.

7. Tindall RS, Rollins JA, Phillips JT, Greenlee RG, Wells L, Belendiuk G. Preliminary results of a double-blind, randomized, placebo-controlled trial of cyclosporine in myasthenia gravis. N Engl J Med. 1987;316(12):719-24. doi:10.1056/NEJM198703193161205

8. Tindall RS, Phillips JT, Rollins JA, Wells L, Hall K. A clinical therapeutic trial of cyclosporine in myasthenia gravis. Ann N Y Acad Sci. 1993;681 1 Myasthenia GR:539-51. doi:10.1111/j.1749-6632.1993.tb22937.x

9. Tonali P, Padua L, Sanguinetti C, Padua R, Romanini E, Amadio P. Outcome research and patient-oriented measures in the multiperspective assessment of neurological and musculoskeletal disorders. Consensus Conference: Third Roman Neurophysiology Day, Outcome Research in Neurology and in Musculoskeletal Disorders - 24 October 1998. Ital J Neurol Sci. 1999;20(2):139-40. doi:10.1007/s100720050022

10. Raggi A, Leonardi M, Antozzi C, Confalonieri P, Maggi L, Cornelio F et al. Concordance between severity of disease, disability and health-related quality of life in myasthenia gravis. Neurol Sci. 2010;31(1):41-5. doi:10.1007/s10072-009-0167-y

11. Leonardi M, Raggi A, Antozzi C, Confalonieri P, Maggi L, Cornelio $F$ et al. The relationship between health, disability and quality of life in myasthenia gravis: results from an Italian study. J Neurol. 2010;257(1):98-102. doi:10.1007/s00415-009-5279-z

12. Morris J, Perez D, McNoe B. The use of quality of life data in clinical practice. Qual Life Res. 1998;7(1):85-91. doi:10.1023/A:1008893007068

13. Padua L, Evoli A, Aprile I, Caliandro P, Batocchi AP, Punzi C et al. Myasthenia gravis outcome measure: development and validation of a disease-specific self-administered questionnaire. Neurol Sci. 2002;23(2):59-68. doi:10.1007/s100720200027

14. Wolfe GI, Herbelin L, Nations SP, Foster B, Bryan WW, Barohn RJ. Myasthenia gravis activities of daily living profile. Neurology. 1999;22;52(7):1487. doi:10.1212/WNL.52.7.1487

15. Muppidi S. The myasthenia gravis: specific activities of daily living profile. Ann N Y Acad Sci. 2012;1274(1):114-9. doi:10.1111/j.1749-6632.2012.06817.x

16. Burns TM, Grouse CK, Conaway MR, Sanders DB. Construct and concurrent validation of the MG-QOL15 in the practice setting. Muscle Nerve. 2010;41(2):219-6. doi:10.1002/mus.21609

17. Besinger UA, Toyka KV, Hömberg M, Heininger K, Hohlfeld R, Fateh-Moghadam A. Myasthenia gravis: long-term correlation of binding and bungarotoxin blocking antibodies against acetylcholine receptors with changes in disease severity. Neurology. 1983;33(10):1316-21. doi:10.1212/WNL.33.10.1316
18. Burns TM, Conaway MR, Cutter GR, Sanders DB Construction of an efficient evaluative instrument for myasthenia gravis: the MG composite. Muscle Nerve. 2008;38(6):1553-62. doi:10.1002/mus.21185

19. Mourão AM, Araújo CM, Barbosa LS, Gomez RS, Burns TM, Lemos $S M$ et al. Brazilian cross-cultural translation and adaptation of the "Questionnaire of Life Quality Specific for Myasthenia Gravis - 15 items”. Arq. Neuropsiquiatr. 2013;71(12):955-58. doi:10.1590/0004-282X20130180

20. Sadjadi R, Conaway M, Cutter G, Sanders DB, Burns TM. Psychometric evaluation of the myasthenia gravis composite using Rasch analysis. Muscle Nerve. 2012;45(6):820-5. doi:10.1002/mus.23260

21. Guillemin F, Bombardier C, Beaton D. Cross-cultural adaptation of health-related quality of life measures: literature review and proposed guidelines. J Clin Epidemiol. 1993;46(12):1417-32. doi:10.1016/0895-4356(93)90142-N

22. Guillemin F. Cross-cultural adaptation and validation of health status measures. Scand J Rheumatol. 1995;24(2):61-3. doi:10.3109/03009749509099285

23. Reichenheim ME, Moraes CL. Operationalizing the crosscultural adaptation of epidemological measurement instruments. Rev Saúde Pública. 2007;41(4):665-73. doi:10.1590/S0034-89102006005000035

24. Maher CG, Latimer J, Costa LOP. The relevance of crosscultural adaptation and clinimetrics for physical therapy instruments. Rev Bras Fisioter. 2007;11(4):245-52. doi:10.1590/S1413-35552007000400002

25. Beaton D, Bombardier C, Guillemin F, Ferraz MB. Guidelines for process of cross-cultural adaptation of self-report measures. Spine. 2000;(25)24:3186-91. doi:10.1097/00007632-200012150-00014

26. Oliveira EF, Urbano JJ, Santos IR, Silva AS, Guimarães LL, Peixoto RAO et al. Brazilian translation, cross-cultural adaptation and validation of the MG Composite scale and Quantitative Myasthenia gravis testing form: a multicentric study protocol. Man Ther Posturology Rehabil J. 2016;14:1-5. doi:10.17784/mtprehabjournal.2016.14.342

27. Benatar M, Sanders DB, Burns TM, Cutter GR, Guptill JT, Baggi F et al. Recommendations for myasthenia gravis clinical trials. Muscle Nerve. 2012;45(6):909-17. doi:10.1002/mus.23330

28. Burns TM, Conaway M, Sanders DB, MG Composite and MG-QOL15 Study Group. The MG Composite. A valid and reliable outcome measure for myasthenia gravis. Neurology. 2010;74(18):1434-40. doi:10.1212/WNL.0b013e3181dc1b1e

29. Burns TM. The MG composite: an outcome measure for myasthenia gravis for use in clinical trials and everyday practice. Ann NY Acad Sci. 2012;1274(1):99-106. doi:10.1111/j.1749-6632.2012.06812.x

30. Morris J, Perez D, McNoe B. The use of quality of life data in clinical practice. Qual Life Res;1998;7(1):85-91. doi:10.1023/A:1008893007068 